\title{
Validation of learning environment inventory for secondary school contexts
}

\author{
Nurulhuda Md Hassan', Norliza Abdul Majid², Nur Khairunnasuha Abu Hassan ${ }^{3}$ \\ 1,2Department of Educational Studies, Sultan Idris Education University, Malaysia \\ ${ }^{3}$ Sultan Idris Education University, Malaysia
}

\begin{abstract}
Article Info
\section{Article history:}

Received Dec 13, 2019

Revised Jan 29, 2020

Accepted Apr 30, 2020

\section{Keywords:}

Confirmatory factor analysis Exploratory factor analysis Learning environment

ABSTRACT

This study was conducted to describe the validation of learning environment inventory (LEI) for secondary school contexts. A survey method was used for data collection through the 20-item LEI. This study consists of two phases. In Phase 1, an exploratory factor analysis (EFA) was conducted using the Statistical Package for Social Sciences (SPSS 21) involving data collected from 150 students, which resulted in the extraction of four factors related to learning environment; (a) Learner-centered, (b) Knowledge-centered, (c) Assessment-centered, and (d) Community-centered. A confirmatory factor analysis (CFA) was carried out in Phase 2 with a new sample $(\mathrm{N}=268)$ which resulted in strong model fit estimation. Such results confirmed the factor structure of Phase 1 and resulted in a final 12-item scale, which may be considered as an acceptable model.
\end{abstract} Validation
This is an open access article under the CC BY-SA license.

\section{Corresponding Author:}

Nurulhuda Md Hassan,

Department of Educational Studies,

Faculty of Human Development,

Sultan Idris Education University,

35900 Tanjong Malim, Perak, Malaysia.

Email: nurulhuda.mh@fpm.upsi.edu.my

\section{INTRODUCTION}

Learning environment has been a major concern in educational research after it was introduced by Lewin [1] and Murray [2], due to its cucial role in determining the extent to which the teaching and learning process is effective [3,4]. It implies a variety of aspects that influence students' intellectual development, which include psychological, emotional, social, and cultural [5]. Higher academic achievement among students due to the exposure to positive classroom environments is consistent with developmental theory, even though it is not yet well documented in the educational literature [6].

The literature is replete with evidence that shows learning environment has the potential to influence students' academic achievement [7-27]. The new reform in education emphasizes the need for creating collaborative and learner centered learning environments. However, most teachers were found to be continually practicing traditional approach, especially in secondary schools [28]. They preferred to use lecture as their primary teaching method $[3,29]$ and emphasized summative rather than formative assessment. These practices led to poor students' participation which eventually resulted in substandard student performance.

\section{BRANSFORD, BROWN AND COCKING LEARNING ENVIRONMENT MODEL}

The learning environment model introduced by Bransford, Brown, and Cocking [30] sought to ensure that a holistic learning environment is provided to students by taking into account various aspects that affect 
students' development. These aspects include psychological, emotional, social, and cultural [5]. The model has four different dimensions that mutually support each other, namely, learner-centered, knowledge-centered, assessment-centered, and community-centered. Reviews of the literature confirmed the importance of including the characteristics of those dimensions in improving student achievement [5, 31-34].

Learner-centered environments refer to the learning environments that attend to students' pre-existing knowledge, skills, attitudes, and beliefs. Besides, it also entails the importance of integrating students' cultural background into the teaching and learning process and having a sense of respect for the students' language practices in order to help students engage in meaningful learning. Learner-centered environments help students to construct meaning by establishing a connection between students' prior knowledge, skills, attitudes, and beliefs with current learning through active learning $[35,36]$.

In order to provide learner-centered environments, it is crucial for teachers to draw out students' preconceptions to be used as the basis for a more formal understanding of what is being learnt [37]. This requires teachers to practice learner-centered approaches in their classrooms, such as diagnostic and responsive teaching [38-40]. Besides, teachers are also expected to link what is learnt in the classroom to the real world experience encountered by students outside the school setting, as an approach to cultivate authentic learning $[35,36]$.

Knowledge-centered environments put strong emphasis on learning with understanding and subsequent transfer. Inaddition, such environments also stress on sense-making through metacognitive approaches [41-43] that can help students to become metacognitive experts, who can regulate their own learning. Learning with understanding involves the ability to organize knowledge in a meaningful pattern [44], while transfer entails the ability to apply knowledge in multiple contexts [45]. In order to encourage learning with understanding and learning transfer, knowledge-centered environments focus on the information and activities that are believed to help students develop an in-depth and integrated understanding of a particular discipline. Besides, such environments also require the teaching of major concepts in various contexts [46] to promote learning transfer.

Assessment-centered environments highlight the importance of continuous feedback in improving student learning [47]. In order to be effective, such feedback should be on time, specific, understandable, and provides room for improvement [48]. Besides that, these environments also require that assessments are designed to assess students' understanding and provide opportunities for students to enhance their learning [49]. This model put greater emphasis on formative assessments since they can provide information about students' level of understanding continuously. Apart from that, such environments also stress the importance of developing self-assessment skills among students in order to help them monitor their own learning [50].

Community-centered environments put a strong emphasis on the establishment of positive norms to learn from each other through the collaboration among learning community members. In this environment, teachers and students are given freedom to make mistakes in order to improve students' learning [51, 52]. To promote such environments, learning community members, including those inside and outside of school setting, need to work together to achieve common learning goals [53]. Learning community inside the school setting, which involves classroom and school community, can be promoted through cooperative learning approaches $[54,55]$. Meanwhile, the learning community outside school setting which entails the connections between classroom learning experience and out-of-school learning experience can be promoted through after-school programs [56].

According to Bransford, Brown and Cocking [30], incorporating the elements of learner-centered, knowledge-centered, assessment-centered, and community-centered learning environments can optimize students' learning. This study was conducted to (i) explore the four dimensions of learning environment model proposed by Bransford, Brown and Cocking [30] using Exploratory Factor Analysis (EFA), and (ii) test the adequacy of the measurement model by using the Confirmatory Factor Analysis (CFA).

\section{RESEARCH METHOD}

A survey method was used for data collection through the 20-item LEI which was developed according to the four dimensions of learning environment proposed by Bransford, Brown and Cocking [30]. In total, 418 secondary school students responded to the questionnaire. From this number, data from 150 students were subjected to the Exploratory Factor Analysis (EFA) involving Principal Component Analysis (PCA) with varimax rotation, in order to obtain possible factors of the LEI. EFA of the data from this group was carried out using Statistical Package for Social Sciences Version 21 (SPSS 21). Prior to EFA, Kaiser-Meyer-Olkin (KMO) and Barlett's Sphericity Test were conducted to determine the adequacy of the sample and to indicate the extent to which the data fit to the factor analysis. Next, data from 268 students were subjected to the Confirmatory Factor Analysis (CFA) in order to cross-validate the results obtained from EFA. In this regard, the acceptable indexes for CFAwere $\left[1<\right.$ Normed Chisquare $\left(\chi^{2} / \mathrm{df}\right)<5$, 
Comparative Fit Index $(\mathrm{CFI}) \geq 0.90$, and $0.03<$ Root Mean Square Error of Approximation (RMSEA) < 0.08], as recommended by Hair et al. [57].

\section{RESULTS AND DISCUSSION}

The obtained results for Kaiser-Meyer-Olkin (KMO) measure of sampling adequacy was 0.873 and Bartlett's Test of Sphericity was significant $(p<.001)$. These results indicate the strong inter-correlations among the items in the questionnaire which allows factor analysis to be carried out. A Principal Component Analysis (PCA) followed by Varimax rotation resulted in the extraction of four factors which explain 53.604\% of the variance. Individually, the extracted factors could account for $33.88 \%, 7.2 \%, 6.585 \%$, and $5.939 \%$ of the total variance. Four aspects were taken into account in deciding the number of factors to be retained; 1) interpretability of the results, 2) the factors explaining over 1 Eigenvalue, 3) the parallel analysis, and 4) the minimum average partial correlation. Additionally, consideration was also given to the theoretical background of the questionnaire. In this regard, the researchers adhered to Hair et al.'s [57] recommendations to ensure a more accurate decision regarding the number of factors.

12 out of 20 items were acceptably loaded on the four factors after checking the factor loadings. The removal of items with loadings lower than .30 and those that clearly loaded on more than one factor, reduced the 20-item scale to a 12-item one. Items 1, 2 and 5 were loaded on factor 1, items 17, 18 and 19 were loaded on factor 2, items 11, 12 and 16 were loaded on factor 3, and items 7, 9 and 10 were loaded on factor 4. The groupings of the particular items were indicated by the factor loadings of the 12-item questionnaire. In order to interpret the groupings of items, the items clustered together under the same factor were studied carefully. This was done to find out if there was any commonality among the items and whether items grouped together could create a new underlying construct.

A closer scrutiny of the first factor content, which explained $33.88 \%$ of the total variance, showed that all the items are in line with the characteristics of learner-centered learning environment. Therefore, this factor was labeled as Learner-Centered Learning Environment.The three items that were loaded in the second factor, which explains $7.2 \%$ of the total variance, were related to community-centered learning environment, and was labeled as Community-Centered Learning Environment. The third factor, explaining $6.585 \% \mathrm{f}$ the total variance, consists of items related to assessment-centered learning environment and was labeled as Assessment-Centered Learning Environment. Further, the three items in the fourth factor, which explains $5.939 \%$ of the total variance, were related to knowledge-centered learning environment. It was correctly labeled as Knowledge-Centered Learning Environment. Table 1 depicts the total variance explained for each factor, while Table 2 shows the grouping and loading of allthe items onto the four factors in the EFA.

Confirmatory Factor Analysis (CFA) was conducted with a new set of data $(n=268)$ in order to test the model fitness.The results yielded that learning environment dimensions were rather adequate with chi square $(\chi 2)=82.202$, degree of freedom $(\mathrm{df})=48$, significant level $(\mathrm{p})=0.000$ and normed chi-square $(\chi 2 / \mathrm{df})=1.713$. The incremental fitness result indicated model fit; Comparative Fit Index $(\mathrm{CFI})=0.941$. The absolute fitness result showed an excellent model fit; Root Mean Square Error of Approximation $($ RMSEA $)=0.052$. Figure 1 depicts the results obtained from CFA.

Table 1. Total variance explained

\begin{tabular}{|c|c|c|c|}
\hline \multirow{2}{*}{ Component } & \multicolumn{3}{|c|}{ Initial } \\
\hline & Eigenvalues & $\%$ of Variance & Cumulative \\
\hline 1 & 6.776 & 33.880 & 15.447 \\
\hline 2 & 1.440 & 7.200 & 41.080 \\
\hline 3 & 1.317 & 6.585 & 47.665 \\
\hline 4 & 1.188 & 5.939 & 53.604 \\
\hline
\end{tabular}




\begin{tabular}{|c|c|c|c|}
\hline $\begin{array}{c}\text { Learning } \\
\text { Environment }\end{array}$ & $\begin{array}{c}\text { Factor } \\
\text { Item }\end{array}$ & Indicators & $\begin{array}{c}\text { Factor } \\
\text { Loadings }\end{array}$ \\
\hline \multirow{2}{*}{$\begin{array}{l}\text { 1) Learner- } \\
\text { Centered }\end{array}$} & L2 & Teachers relate what I've learned in the classroom with my experience in real life. & 0.389 \\
\hline & L5 & Teachers use easy-to-understand language when teaching. & 0.559 \\
\hline \multirow{2}{*}{$\begin{array}{l}\text { 2) Community- } \\
\text { Centered }\end{array}$} & L17 & Teachers encourage me to learn with my friends while conducting learning activities. & 0.513 \\
\hline & L19 & $\begin{array}{l}\text { Teachers create a positive social environment where teachers and students are open to } \\
\text { make mistakes during the teaching and learning process. }\end{array}$ & 0.463 \\
\hline \multirow{3}{*}{$\begin{array}{l}\text { 3) Assessment- } \\
\text { Centered }\end{array}$} & L11 & Teachers give me the opportunity to evaluate my own learning. & 0.469 \\
\hline & L12 & Teachers give me the opportunity to evaluate the work of my friends. & 0.487 \\
\hline & L16 & $\begin{array}{l}\text { Teachers give me the opportunity to share ideas when learning a particular topic in } \\
\text { the classroom. }\end{array}$ & 0.439 \\
\hline
\end{tabular}

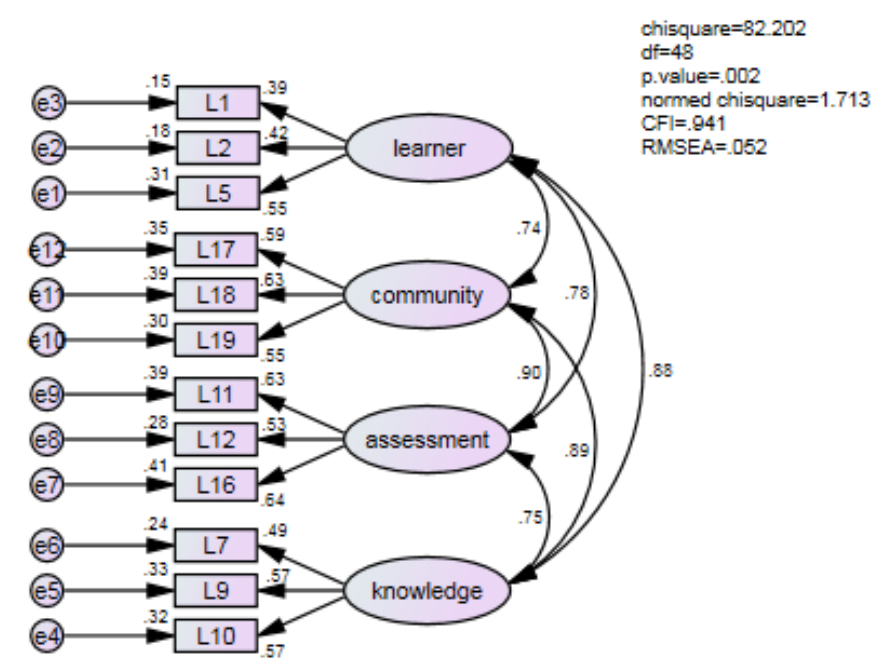

Figure 1. Measurement model of the LEI

\section{CONCLUSION}

This study was conducted to validate a measuring instrument related to a learning environment called Learning Environment Inventory (LEI). Four learning environment dimensions served as the conceptual model for developing the instrument and its validation. The results obtained from EFA yielded that four factors can be extracted by the instrument, which were in line with the conceptual model. Additionally, all the parameters obtained from CFA indicated that this model is an acceptable model. Therefore, it can be concluded that LEI is a valid instrument. However, care should be taken for wider application of the tested model and the developed LEI, since this study focused only on secondary school students from one of the states in Malaysia as samples. For future research, cross-validation of LEI is recommended by including a larger number of secondary school students in Malaysia.

\section{ACKNOWLEDGEMENTS}

This research work wassupported by the Research Management and Innovation Centre, Sultan Idris Education University under University Research Grant 2018-0127-106-01. The researchers also acknowledge with gratitude the support from the Selangor Education Department for data collection.

\section{REFERENCES}

[1] Lewin, K., Principles of Topological Psychology. New York: McGraw-Hill, 1936.

[2] Murray, H. A., Explorations in Personality. New York: Oxford University Press, 1938. 
[3] Afari, E., Aldridge, J. M. and Fraser, B. J., "Effectiveness of using games in tertiary-level mathematics classrooms," International Journal of Science and Mathematics Education, vol. 10, no. 6, pp. 1369-1392, 2012.

[4] Robinson, E. and Fraser, B. J, "Kindergarten students' and parents' perceptions of science classroom environments: Achievement and attitudes," Learning Environments Research, vol. 16, no. 2, pp. 151-167, 2013.

[5] Afari, E., et al, "Students' perceptions of the learning environment and attitudes in game-based mathematics classrooms," Learning Environments Research, vol. 16, no. 1, pp. 131-150, 2013.

[6] Allen, J., Gregory, A., Lun, J., Hamre, B. and Pianta, R, "Observations of effective teacher-student interactions in secondary school classroom: Predicting student achievement with the classroom assessment scoring systemsecondary," School Psychology Review, vol. 42, no. 1, pp. 76-98, 2013.

[7] Kazu, I. Y., and Demirkol, M., "Effect of blended learning environment model on high school students' academic achievement," Turkish Online Journal of Educational Technology-TOJET, vol. 13, no. 1, pp. 78-87, 2014.

[8] Sidik, I. F., Awang, M. M., and Ahmad, A. R., "Social environmental support in various types of secondary schools in improving soft skills among students (in Malay)," Malaysian Journal of Education, vol 43, no. 3, pp. 67-76, 2018.

[9] Broadbent, J., and Poon, W. L., "Self-regulated learning strategies \& academic achievement in online higher education learning environments: A systematic review," The Internet and Higher Education, vol. 27, pp. 1-13, 2015.

[10] Wang, T. H., "Developing an assessment-centered e-learning system for improving student learning effectiveness," Computers \& Education, vol. 73, pp. 189-203, 2014.

[11] Chen, B. H., and Chiou, H. H., "Learning style, sense of community and learning effectiveness in hybrid learning environment," Interactive Learning Environments, vol. 22, no. 4, pp. 485-496, 2014.

[12] Richardson, C., and Mishra, P., "Learning environments that support student creativity: Developing the SCALE," Thinking Skills and Creativity, vol. 27, pp. 45-54, 2018.

[13] Tran, V. D, "The effects of cooperative learning on the academic achievement and knowledge retention," International journal of higher education, vol. 3, no. 2, pp. 131-140, 2014.

[14] Rasiah, R. R. V., "Transformative higher education teaching and learning: Using social media in a team-based learning environment," Procedia-Social and Behavioral Sciences, vol. 123, pp. 369-379, 2014.

[15] Zhonggen, Y., Ying, Z., Zhichun, Y., and Wentao, C., "Student satisfaction, learning outcomes, and cognitive loads with a mobile learning platform," Computer Assisted Language Learning, vol. 32, no.4, pp. 1-19, 2018.

[16] Alt, D., "Assessing the contribution of a constructivist learning environment to academic self-efficacy in higher education," Learning Environments Research, vol. 18, no. 1, pp. 47-67, 2015.

[17] Tamis-LeMonda, et al, "Early home learning environment predicts children's 5th grade academic skills," Applied Developmental Science, vol. 23, no. 2, pp. 153-169, 2019.

[18] Shamaki, T. A., "Influence of learning environment on students' academic achievement in mathematics: A case study of some selected secondary schools in Yobe State-Nigeria," Journal of Education and Practice, vol. 6, no. 34, pp. 4044, 2015.

[19] Yapici, İ. Ü., "Effectiveness of blended cooperative learning environment in biology teaching: Classroom community sense, academic achievement and satisfaction," Journal of Education and Training Studies, vol. 4, no. 4, pp. 269-280, 2016.

[20] Al-Ghamdi, A., "Building a positive environment in classrooms through feedback and praise," English Language Teaching, vol. 10, no. 6, pp. 37-43, 2017.

[21] Korucu, A. T., and Cakir, H., "The effect of dynamic web technologies on student academic achievement in problembased collaborative learning environment," Malaysian Online Journal of Educational Technology, vol. 6, no. 1, pp. 92-108, 2018.

[22] Malik, R. H., and Rizvi, A. A., "Effect of classroom learning environment on students' academic achievement in mathematics at secondary level," Bulletin of Education and Research, vol. 40, no. 2, pp. 207-218, 2018.

[23] Shoval, E., Sharir, T., Arnon, M., and Tenenbaum, G, "The effect of integrating movement into the learning environment of kindergarten children on their academic achievements," Early Childhood Education Journal, vol. 46, no. 3, pp. 355-364, 2018.

[24] Munawaroh, A., "The use of cooperative learning to improve students' ability in reading comprehension in Mts Nurul Barokah 2017," Journal of English Pedagogy, Linguistics, Literature, and Teaching, vol. 5, no. 1, 2017.

[25] Aktaş, E., and Yurt, S. U., "Effects of digital story on academic achievement, learning motivation and retention among university students," International Journal of Higher Education, vol. 6, no. 1, pp. 180-196, 2017.

[26] Cohn, S. T., and Fraser, B. J., "Effectiveness of student response systems in terms of learning environment, attitudes and achievement," Learning Environments Research, vol. 19, no. 2, pp. 153-167, 2016.

[27] Gündüz, A. Y., et al, "Design of a problem-based online learning environment and evaluation of its effectiveness," Turkish Online Journal of Educational Technology-TOJET, vol. 15, no. 3, pp. 49-57, 2016.

[28] Wachira, P., Pourdavood, R. G. and Skitzki, R., "Mathematics teacher's role in promoting classroom discourse," International Journal for Mathematics Teaching and Learning, pp. 1-38, 2013.

[29] Lee, C. and Johnston-Wilder, S., "Learning mathematics-letting the pupils have their say," Educational Studies in Mathematics, vol. 83, no. 2, pp. 163-180, 2012.

[30] R. R. Bransford, et al., How people learn. Washington, DC: National Academy Press, 2004.

[31] Bowman-Perrott, et al "Academic benefits of peer tutoring: A meta-analytic review of single-case research," School Psychology Review, vol. 42, no. 1, pp. 39-55, 2013.

[32] Kondratieva, M., "Geometrical constructions in dynamic and interactive mathematics learning environment," Mevlana International Journal of Education, vol. 3, no. 3, pp. 50-63, 2013. 
[33] Nasarudin Abdullah, Lilia Halim and Effandi Zakaria, "V Stops: A thinking strategy and visual representation approach in mathematical word problem solving toward enhancing STEM literacy," EURASIA Journal of Mathematics, Science \& Technology Education, vol. 10, no. 3, pp. 165-174, 2014.

[34] Sharifah Fauziah Hanim Syed Zain, et al, "Student-centred learning in mathematics-constructivism in the classroom," Journal of International Education Research, vol. 8, no. 4, pp. 319-328, 2012.

[35] Murdoch, K. and Wilson, J., Creating a Learner-centered Primary Classroom: Learner-Centered Strategic Teaching. New York: Routledge, 2008.

[36] McCombs, B.L and Miller, L., Learner-Centered Classroom Practices and Assessments: Maximizing Student Motivation, Learning, and Achievement. USA: Corwin Press, 2007.

[37] Walker, B.J., Diagnostic Teaching of Reading: Techniques for Instruction and Assessment, $7^{\text {th }}$ Ed. Boston: Pearson, 2011.

[38] Irvin, J.J. and Armento, B.J., Culturally Responsive Teaching: Lesson Planning for Elementary and Middle Grades. New York: McGraw Hill, 2001.

[39] Bowers, C.A. and Flinders, D.J., Responsive Teaching: An Ecological Approach to Classroom Patterns of Language, Culture, and Thought. USA: Teachers College Press, 1990.

[40] Tanner, K. D., "Promoting student metacognition," CBE Life Sciences Education, vol. 11, no. 2, pp. 113-120, 2012.

[41] Miller, T. M. and Geraci, L., "Training metacognition in the classroom: The influence of incentives and feedback on exam predictions," Metacognition and Learning, vol 6, no. 3, pp. 303-314, 2011.

[42] Sandi-Urena, S., Cooper, M. M. and Stevens, R. H., "Enhancement of metacognition use and awareness by means of a collaborative intervention," International Journal of Science Education, vol. 33, no. 3, pp. 323-340, 2011.

[43] Schellenberg, S., et al, "The effects of metacognition and concrete encoding strategy on depth of understanding in educational psychology," Teaching Educational Psychology, vol. 7, no. 2, pp. 17-24, 2011.

[44] Shelley, M., and Yildirim, A., "Transfer of learning in mathematics, science, and reading among students in Turkey: A study using 2009 PISA data," International Journal of Education in Mathematics, Science and Technology, vol. 1, no. 2, pp. 83-95, 2013.

[45] Perin, D., "Facilitating student learning through contextualization: A review of evidence," Community College Review, vol. 39, no. 3, pp. 268-295, 2011.

[46] Carnell, E., Dialogue, Discussion and feedback: Views from secondary school students on how others help their learning. In Askew, S (ed.). Feedback for Learning. London: Routledge Falmer, 2001.

[47] Tomlinson, C.A. and McTighe, J, Integrating Differentiated Instruction and Understanding by Design: Connecting Content and Kids. USA: Association for Supervision and Curriculum Development (ASCD), 2006.

[48] Nitko, A.J. and Brookhart, S.M., Educational Assessment of Students, $6^{\text {th }}$ ed. Boston: Pearson, 2011.

[49] Boud, D., Enhancing Learning through Self-Assessment. London: Kogan Page Limited, 1995.

[50] Lemlech, J.K., Teaching in Elementary and Secondary Classrooms: Building a Learning Community. New Jersey: Pearson Education, 2004.

[51] Donovan, M.S. and Bransford, J.D, How Students Learn: History, Mathematics, and Science in the Classroom. USA: The National Academic Press, 2005.

[52] Kendricks, K. D., "Creating a supportive environment to enhance computer based learning for underrepresented minorities in college algebra classrooms," Journal of the Scholarship of Teaching and Learning, vol. 12, no. 4, pp. 12-25, 2011.

[53] Vargas-Vargas, M., Mondejar-Jimenez, J., Santamaria, M. L. M., Alfaro-Navarro, J. L., and Fernandez-Aviles, G., "Cooperative learning in virtual environments: The jigsaw method in statistical courses," Journal of International Education Research (JIER), vol. 7, no. 5, pp. 1-8, 2011.

[54] Joliffe. W, Cooperative Learning in the Classroom: Putting it into Practice. Wiltshire: Cromwell Press. $2007,2009$.

[55] Roberts, S. M. and Pruitt, E. Z. (Eds.), Schools as Professional Learning Communities: Collaborative Activities and Strategies for Professional Development. Corwin Press, 2008.

[56] Watkins, C., Classrooms as Learning Communities: What's in it for Schools? New York: Routledge, 2005.

[57] Hair, J. F., et al., Mutivariate Data Analysis, $7^{\text {th }}$ ed. New Jersey: Pearson, 2010. 